\title{
Pseudomonas taeanensis sp. nov., isolated from a crude oil-contaminated seashore
}

\author{
Dong-Heon Lee, ${ }^{1}$ Sung-Ran Moon, ${ }^{1}$ Young-Hyun Park, ${ }^{1}$ Jung-Ho Kim, ${ }^{2}$ \\ Hoon Kim, ${ }^{2}$ Rebecca E. Parales ${ }^{3}$ and Hyung-Yeel Kahng ${ }^{1}$ \\ ${ }^{1}$ Department of Environmental Education, Sunchon National University, Sunchon 540-742, \\ Republic of Korea \\ ${ }^{2}$ Department of Biological Environment, Sunchon National University, Sunchon 540-742, Republic \\ of Korea \\ ${ }^{3}$ Department of Microbiology, University of California Davis, Davis, CA 95616, USA
}

Correspondence

Hyung-Yeel Kahng

kahng@sunchon.ac.kr
Many novel Pseudomonas species have been reported and the classification of the genus Pseudomonas has been reassessed several times on the basis of physiological, molecular and phenotypic features (Sneath et al., 1981), DNA-DNA hybridization (Palleroni, 1984), 16S rRNA gene sequence similarity (Anzai et al., 2000) and chemotaxonomic data (Oyaizu \& Komagata, 1983; Vancanneyt et al., 1996). Members of the genus Pseudomonas are ubiquitous and the genus is metabolically possibly the most versatile known so far (Palleroni, 1993; Elkin \& Geddes, 2003; LópezRomalde et al., 2003; Levitski-Heikkila \& Ullian, 2005). A variety of human-made pollutants are degraded by many Pseudomonas strains (Kiyohara et al., 1992; Johnsen et al., 1996; Kahng et al., 2002; Stolz et al., 2007) and Pseudomonas

The GenBank/EMBL/DDBJ accession number for the 16S rRNA gene sequence of strain MS-3 ${ }^{\top}$ is FJ424813.

A transmission electron micrograph of a cell of strain $M S-3^{\top}$ and results from slot-blot DNA-DNA hybridizations and GN2 MicroPlate assays for strain $\mathrm{MS}-3^{\top}$ and its closest relatives are available as supplementary material with the online version of this paper. strains have been applied in the bioremediation of contaminated sites (O’Mahony et al., 2006; Onaca et al., 2007). Successful bioremediation with Pseudomonas strains (Mishra et al., 1999, 2001; Whyte et al., 2001) has stimulated environmental microbiologists to isolate novel strains from diverse environments (Bhattacharya et al., 2003; Prakash et al., 2007) and a number of novel Pseudomonas species with different metabolic capabilities, including Pseudomonas panipatensis (Gupta et al., 2008), have been described. Strain MS- $3^{\mathrm{T}}$ was isolated from an oil-contaminated marine coastal area and was found to be capable of degrading gasoline, diesel and kerosene. Further studies were performed to determine its taxonomic position.

Water samples that were severely contaminated with crude oil were collected from the Taean coastal area in Korea in 2008. Enrichment cultures were performed in a basal salts medium (Mikesell et al., 1993) containing 0.25-2 \% crude oil. Strain $\mathrm{MS}-3^{\mathrm{T}}$ was isolated using a standard serial dilution-plating method on marine agar 2216 (MA; Difco) at $25{ }^{\circ} \mathrm{C}$ for 5 days. Strain MS- $3^{\mathrm{T}}$ was routinely subcultivated on LB agar (Difco) at $30{ }^{\circ} \mathrm{C}$ for 3 days under aerobic 
conditions and stored at $-80{ }^{\circ} \mathrm{C}$ in $\mathrm{LB}$ broth (Difco) supplemented with $15 \%(\mathrm{v} / \mathrm{v})$ glycerol.

Genomic DNA from strain MS-3 $3^{\mathrm{T}}$ was extracted and purified by using a genomic DNA extraction kit (Bioneer) and the 16S rRNA gene was amplified using bacterial universal primers (Weisburg et al., 1991). Sequencing of the 16S rRNA gene was carried out as described by Lane (1991). The nearly complete $16 \mathrm{~S}$ rRNA gene sequence was compared with those available in GenBank using BLAST (http://www. ncbi.nlm.nih.gov/blast/) to determine the approximate phylogenetic affiliation. CLUSTAL w (Thompson et al., 1994) was used to align sequences from closely related taxa. Sequence similarity values were computed using Similarity Matrix version 1.1 (Ribosomal Database Project II; http://rdp.cme. msu.edu/index.jsp) (Cole et al., 2003) and the EzTaxon server (http://www.eztaxon.org/; Chun et al., 2007). Gaps at the $5^{\prime}$ and $3^{\prime}$ ends of the alignment were omitted from further analyses. Phylogenetic trees were constructed using the neighbour-joining method (Saitou \& Nei, 1987) in the MEGA3 software package (Kumar et al., 2004) and bootstrap values were calculated for 1000 replications (Felsenstein, 1985). Evolutionary distance matrices were calculated according to the algorithm of Kimura's two-parameter model (Kimura, 1983). On the basis of 1421 bp, strain MS$3^{\mathrm{T}}$ shared high 16S rRNA gene sequence similarity with Pseudomonas marincola KMM $3042^{\mathrm{T}}$ (97.9\%), P. cuatrocienegasensis $1 \mathrm{~N}^{\mathrm{T}}(97.8 \%)$, P. borbori $\mathrm{R}-2082 \mathrm{1}^{\mathrm{T}}(97.3 \%), P$. lundensis ATCC $49968^{\mathrm{T}}(97.1 \%)$, P. peli $\mathrm{R}-20805^{\mathrm{T}}(97.0 \%)$ and $P$. pohangensis $\mathrm{H} 3-\mathrm{R} 18^{\mathrm{T}}(97.0 \%)$. The phylogenetic tree (Fig. 1) showed that strain MS $-3^{\mathrm{T}}$ formed a separate clade within the genus Pseudomonas and suggested that strain MS- $3^{\mathrm{T}}$ represented a novel species within the genus Pseudomonas.

DNA-DNA hybridization was carried out using the membrane filter technique with a DIG High Prime DNA Labelling and Detection Starter kit II (Roche Molecular Biochemicals). Genomic DNA was denatured by the alkaline method, immobilized on a nylon membrane $\left(\right.$ Hybond- $\mathrm{N}^{+}$; Amersham) by applying vacuum pressure and labelled according to the manufacturer's protocol. The membranes were prehybridized at $45{ }^{\circ} \mathrm{C}$ for $30 \mathrm{~min}$ and hybridization with labelled DNA was performed at $45^{\circ} \mathrm{C}$ for $2 \mathrm{~h}$. After hybridization, the membranes were washed twice at $65{ }^{\circ} \mathrm{C}$ in primary washing solution $(2 \times$ SSC, $0.1 \%$ SDS $)$ and washed twice in secondary washing solution $(0.5 \times$ SSC, $0.1 \%$ SDS $)$. After addition of detection reagents for $5 \mathrm{~min}$ at room temperature, excess liquid was removed and the membranes were exposed to autoradiography film (Hyperfilm-ECL; Amersham) for $15 \mathrm{~min}$. Signal intensities were determined using the program TINA 2.0. The signal produced by selfhybridization was taken as $100 \%$. DNA-DNA relatedness was calculated from duplicate samples. Strain MS- $3^{\mathrm{T}}$ showed relatively low DNA-DNA relatedness to $P$. cuatrocienegasensis LMG $24676^{\mathrm{T}}(57.2 \%)$, P. borbori LMG $23199^{\mathrm{T}}$ (39.7\%), P. marincola KMM $3042^{\mathrm{T}}(32.2 \%)$ and $P$. lundensis KACC $10832^{\mathrm{T}}$ (32.1\%) (Supplementary Fig. S1, available in IJSEM Online). These values were lower than

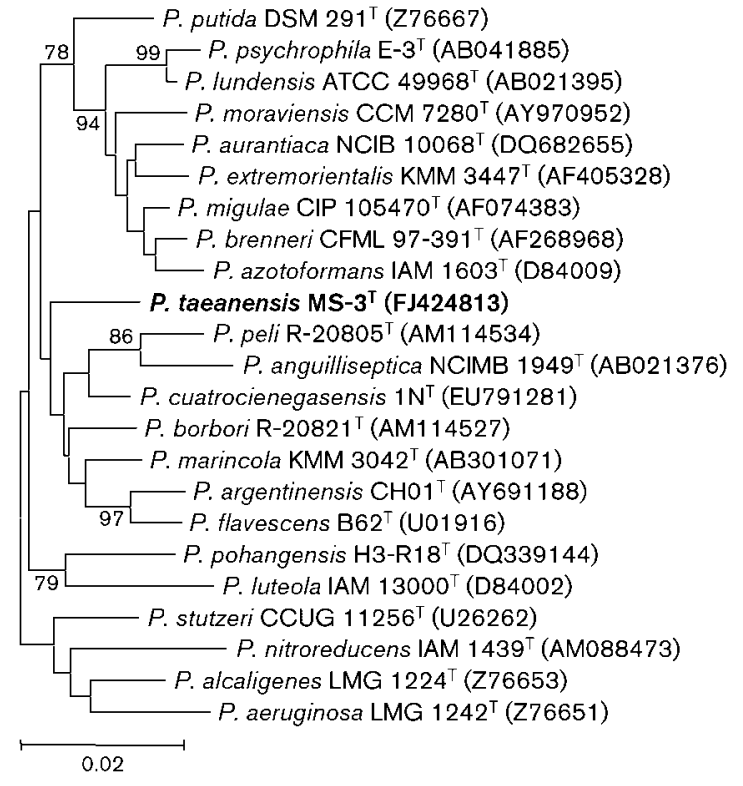

Fig. 1. Neighbour-joining phylogenetic tree based on $16 \mathrm{~S}$ rRNA gene sequences showing the relationships between strain MS- $3^{\top}$ and its closest relatives in the genus Pseudomonas. Bootstrap values $(>70 \%)$ based on 1000 replications are shown at branch nodes. Escherichia coli ATCC $11775^{\top}$ (GenBank accession no. X08725) was used as an outgroup (not shown). Bar, 0.02 substitutions per nucleotide position.

$70 \%$, the threshold value recommended for the delineation of species (Wayne et al., 1987), which supported the conclusion from the 16S rRNA gene sequence data that strain $\mathrm{MS}-3^{\mathrm{T}}$ represented a novel species in the genus Pseudomonas.

Cells of strain MS- $3^{\mathrm{T}}$ were grown aerobically on LB agar at $30{ }^{\circ} \mathrm{C}$ for 3 days. Cell morphology and size were studied using phase-contrast and transmission electron microscopy (JEM-1010; JEOL) as described by Bernardet et al. (2002). Cells of strain $\mathrm{MS}-3^{\mathrm{T}}$ were motile and had a single flagellum (Supplementary Fig. S2). Growth of strain MS-3 ${ }^{\mathrm{T}}$ on LB agar was determined at $4-40{ }^{\circ} \mathrm{C}$ and at $\mathrm{pH} 4.0-11.0$ (at intervals of $0.5 \mathrm{pH}$ units), with the $\mathrm{pH}$ adjusted with $1 \mathrm{M} \mathrm{HCl}$ or $\mathrm{NaOH}$. Growth with $0-10 \%(w / v) \mathrm{NaCl}$ (at intervals of $1 \% \mathrm{NaCl}$ ) was determined in LB broth. Flagellar motility was examined by using wet mounts made from fresh cultures grown at $30{ }^{\circ} \mathrm{C}$ for 2 days, according to the method described by Bowman (2000). The Gram reaction was determined by using a Gram stain kit (bioMérieux), according to the manufacturer's instructions. Production of pyocyanin and formation of fluorescent pigments were tested on King A and King B medium, respectively (King et al., 1954). Catalase activity was evaluated by the production of oxygen bubbles in $3 \%$ (v/v) $\mathrm{H}_{2} \mathrm{O}_{2}$ and oxidase activity was tested by oxidation of a $1 \%(\mathrm{w} / \mathrm{v}) \quad N, N, N^{\prime}, N^{\prime}$-tetramethyl-p-phenylenediamine solution. Anaerobic growth was tested on LB agar under 
anaerobic conditions using the GasPak anaerobic system (BBL) at $30{ }^{\circ} \mathrm{C}$ for 20 days. Hydrolysis of casein, chitin, starch, CM-cellulose, DNA and Tweens 20, 40, 60 and 80 was examined on LB agar with $1 \%$ substrate, as described by Hansen \& Sørheim (1991). Other phenotypic features of strain MS- $3^{\mathrm{T}}$ were determined using the API 20E, API 20NE and API ZYM kits (bioMérieux), according to the manufacturer's instructions. Utilization of different carbon sources was determined using GN2 MicroPlates (Biolog) after $48 \mathrm{~h}$ at $30{ }^{\circ} \mathrm{C}$, according to the manufacturer's instructions. Antibiotic sensitivity was tested by spreading cell suspensions on LB agar and applying discs containing the following ( $\mu \mathrm{g}$ per disc, unless otherwise indicated): ampicillin (10), carbenicillin (100), erythromycin (15), gentamicin (10), kanamycin (30), lincomycin (15), neomycin (30), nalidixic acid (30), novobiocin (5), oleandomycin (15), penicillin (10 U), polymyxin B (300) and tetracycline (30). The phenotypic characteristics of strain MS $-3^{\mathrm{T}}$ are given in Table 1 , Supplementary Table S1 and the species description.

The whole-cell fatty acid compositions of strain MS- $3^{\mathrm{T}}$ and reference strains were analysed according to the instructions of the Microbial Identification System (Microbial ID) using cells grown on TSA at $30{ }^{\circ} \mathrm{C}$ for 3 days. The major respiratory quinones were analysed by the Korean Culture Center of Microorganisms, Seoul, Republic of Korea, using reversed-phased HPLC (Komagata \& Suzuki, 1987). The $\mathrm{G}+\mathrm{C}$ content of the DNA was determined by the thermal denaturation method (Marmur \& Doty, 1962) using an Ultrospec 2100 spectrophotometer (Pharmacia Biotech). DNA from Escherichia coli K-12 was used as a control. The fatty acid compositions of strain MS- $3^{\mathrm{T}}$ and the two reference strains are compared in Table 2. The major cellular fatty acids of strain MS- $3^{\mathrm{T}}$ were summed feature 3 (iso- $\mathrm{C}_{15: 0} 2-\mathrm{OH}$ and/or $\mathrm{C}_{16: 1} \omega 7 c ; 38.0 \%$ ), $\mathrm{C}_{16: 0}(24.4 \%$ ), $\mathrm{C}_{18: 1} \omega 7 c(12.8 \%), \mathrm{C}_{12: 0}(9.6 \%)$ and $\mathrm{C}_{10: 0} 3-\mathrm{OH}(4.9 \%)$. The major respiratory quinone was ubiquinone-9 (Q-9) and the $\mathrm{G}+\mathrm{C}$ content of the genomic DNA was $57.6 \mathrm{~mol} \%$.

On the basis of the phenotypic characterization and phylogenetic analysis, strain MS- $3^{\mathrm{T}}$ represents a novel species of the genus Pseudomonas, for which the name Pseudomonas taeanensis sp. nov. is proposed.

\section{Description of Pseudomonas taeanensis sp. nov.}

Pseudomonas taeanensis (ta.e.an.en'sis. N.L. fem. adj. taeanensis pertaining to Taean, Korea, where the type strain was isolated).

Cells are aerobic, Gram-negative, non-pigmented, rodshaped (1.8-2.5 $\mu \mathrm{m}$ long and $0.8-1.0 \mu \mathrm{m}$ wide) and motile with a single flagellum. Colonies are smooth, nonpigmented, whitish and translucent $(2-3 \mathrm{~mm}$ in diameter). No production of pyocyanin on King A medium or fluorescent pigments on King B medium is observed. Grows with $0-5 \%(\mathrm{w} / \mathrm{v}) \mathrm{NaCl}$, at $4-30{ }^{\circ} \mathrm{C}$ (optimum $25-$ $28{ }^{\circ} \mathrm{C}$ ) and at $\mathrm{pH}$ 6.0-9.5 (optimum pH 6.5-8.0). Cells are
Table 1. Phenotypic characteristics of strain $M S-3^{\top}$ and its closest relatives in the genus Pseudomonas

Strains: 1, Pseudomonas taeanensis sp. nov. MS-3 $3^{\mathrm{T}} ; 2$, P. marincola KMM $3042^{\mathrm{T}} ; 3$, P. cuatrocienegasensis LMG $24676^{\mathrm{T}} ; 4$, P. borbori LMG $23199^{\mathrm{T}}$; 5, P. lundensis KACC $10832^{\mathrm{T}}$. All data were obtained in this study. + , Positive; w, weakly positive; - , negative.

\begin{tabular}{|c|c|c|c|c|c|}
\hline Characteristic & 1 & 2 & 3 & 4 & 5 \\
\hline Fluorescent pigments & - & - & + & - & + \\
\hline Nitrate reduction & + & + & - & + & - \\
\hline Acetoin production & + & - & - & - & + \\
\hline \multicolumn{6}{|l|}{ Growth at/with: } \\
\hline $4^{\circ} \mathrm{C}$ & + & + & - & - & + \\
\hline $37^{\circ} \mathrm{C}$ & - & + & - & - & - \\
\hline $5 \% \mathrm{NaCl}$ & + & + & - & - & + \\
\hline \multicolumn{6}{|l|}{ Hydrolysis of: } \\
\hline Gelatin & - & - & + & - & - \\
\hline Tween 80 & + & + & - & + & - \\
\hline \multicolumn{6}{|l|}{ Enzyme activity } \\
\hline Arginine dihydrolase & - & - & + & - & + \\
\hline Alkaline phosphatase & - & + & + & - & + \\
\hline Esterase & $\mathrm{w}$ & - & $\mathrm{w}$ & - & - \\
\hline Esterase lipase & + & + & + & + & - \\
\hline Lipase & - & - & + & - & - \\
\hline Leucine arylamidase & + & - & + & + & + \\
\hline Valine arylamidase & - & - & $\mathrm{w}$ & - & $\mathrm{w}$ \\
\hline Trypsin & - & - & + & $\mathrm{W}$ & + \\
\hline$\alpha$-Chymotrypsin & - & + & - & - & - \\
\hline Acid phosphatase & + & + & + & - & + \\
\hline Naphthol-AS-BI-phosphohydrolase & + & - & - & + & + \\
\hline \multicolumn{6}{|l|}{ Utilization of: } \\
\hline Arabinose & - & - & - & - & + \\
\hline Glucose & + & - & + & + & + \\
\hline Mannitol & + & - & - & - & - \\
\hline Maltose & - & - & - & + & - \\
\hline Gluconate & + & - & - & + & + \\
\hline Caprate & - & + & + & + & + \\
\hline Citrate & + & - & + & + & + \\
\hline Phenylacetate & + & - & + & + & + \\
\hline Glycerol & - & - & - & - & + \\
\hline
\end{tabular}

oxidase- and catalase-positive, but urease- and DNasenegative. Nitrate is reduced to nitrite; nitrite is not reduced. Tweens 20, 40, 60 and 80 are hydrolysed, but casein, gelatin, aesculin, starch, CM-cellulose and chitin are not hydrolysed. With API 20E, cells produce acetoin (Voges-Proskauer reaction), do not produce indole or $\mathrm{H}_{2} \mathrm{~S}$ and are negative for $\beta$-galactosidase, arginine dihydrolase, lysine decarboxylase, ornithine decarboxylase and tryptophan deaminase. With API 20NE, negative for assimilation of arabinose, mannose, $\mathrm{N}$-acetylglucosamine, maltose, caprate, adipate and phenylacetate, gelatinase activity and fermentation of D-glucose and positive for assimilation of glucose, mannitol, gluconate, malate and citrate. With API ZYM, positive for esterase (C4), esterase lipase (C8), leucine arylamidase, acid phosphatase and naphthol-AS-BI-phosphohydrolase, but negative for alkaline phosphatase, lipase (C14), valine arylamidase, cystine arylamidase, trypsin, $\alpha$-chymotrypsin, $\alpha$ - and $\beta$-galactosidases, 
Table 2. Cellular fatty acid compositions of strain $M S-3^{\top}$ and its closest relatives in the genus Pseudomonas

Strains: 1 , P. taeanensis sp. nov. MS-3 $3^{\mathrm{T}} ; 2$, P. marincola KMM $3042^{\mathrm{T}}$; 3, P. cuatrocienegasensis LMG $24676^{\mathrm{T}}$; 4 , P. borbori LMG $23199^{\mathrm{T}} ; 5, P$. lundensis KACC $18032^{\mathrm{T}}$. Data are percentages of total fatty acids and were obtained in this study. ECL, Equivalent chain-length; -, not detected or $<1 \%$ of the total fatty acid content.

\begin{tabular}{|c|c|c|c|c|c|}
\hline Fatty acid & 1 & 2 & 3 & 4 & 5 \\
\hline \multicolumn{6}{|l|}{ Straight chain } \\
\hline $\mathrm{C}_{12: 0}$ & 9.6 & 13.1 & 15.2 & 4.6 & 2.8 \\
\hline $\mathrm{C}_{14: 0}$ & - & - & 1.8 & - & - \\
\hline $\mathrm{C}_{15: 0}$ & 2.0 & - & 1.7 & 1.6 & - \\
\hline $\mathrm{C}_{16: 0}$ & 24.4 & 21.5 & 21.9 & 21.5 & 27.6 \\
\hline $\mathrm{C}_{17: 0}$ & 1.7 & - & - & 1.2 & - \\
\hline $\mathrm{C}_{17: 0}$ cyclo & 1.2 & 5.8 & - & - & 17.1 \\
\hline $\mathrm{C}_{18: 0}$ & - & 1.6 & - & - & - \\
\hline $\mathrm{C}_{19: 0}$ cyclo $\omega 8 \mathrm{c}$ & - & - & - & - & 2.6 \\
\hline \multicolumn{6}{|l|}{ Unsaturated } \\
\hline $\mathrm{C}_{17: 1} \omega 8 c$ & 1.3 & - & - & 1.6 & - \\
\hline $\mathrm{C}_{18: 1} \omega 7 c$ & 12.8 & 22.6 & 26.8 & 13.9 & 6.1 \\
\hline \multicolumn{6}{|l|}{ Hydroxy } \\
\hline $\mathrm{C}_{10: 0} 3-\mathrm{OH}$ & 4.9 & 6.4 & 5.8 & 4.1 & 5.2 \\
\hline $\mathrm{C}_{12: 0} 2-\mathrm{OH}$ & - & - & - & - & 6.8 \\
\hline $\mathrm{C}_{12: 0} 3-\mathrm{OH}$ & 2.2 & 2.5 & 3.7 & 2.2 & 4.2 \\
\hline $\mathrm{C}_{17: 0} 3-\mathrm{OH}$ & - & - & - & - & 5.6 \\
\hline Summed feature $3^{*}$ & 38.0 & 22.7 & 18.8 & 34.8 & 15.7 \\
\hline ECL 11.799 & - & - & - & 3.1 & - \\
\hline
\end{tabular}

* Summed features represent groups of two or three fatty acids that cannot be separated by the Microbial Identification System. Summed feature 3 consisted of iso- $\mathrm{C}_{15: 0} 2-\mathrm{OH}$ and/or $\mathrm{C}_{16: 1} \omega 7 c$.

$\beta$-glucuronidase, $\alpha$-glucosidase, $N$-acetyl- $\beta$-glucosaminidase, $\beta$-glucosaminidase, $\alpha$-mannosidase and $\alpha$-fucosidase. With GN2 MicroPlates, utilizes Tweens 40 and 80, D-fructose, $\alpha$-Dglucose, D-mannitol, methyl pyruvate, formic acid, D-gluconic acid, $\beta$-hydroxybutyric acid, $\alpha$-ketoglutaric acid, DL-lactic acid, succinic acid, L-alaninamide, D- and L-alanine, L-alanyl glycine, L-asparagine, L-aspartic acid, L-glutamic acid, Lhistidine, hydroxy-L-proline, L-leucine, L-proline, L-pyroglutamic acid, D-serine, DL-carnitine, $\gamma$-aminobutyric acid and putrescine; all other carbon sources included in the GN2 MicroPlate are not utilized. Resistant to ( $\mu$ g per disc, unless indicated) ampicillin (10), erythromycin (15), lincomycin (15), oleandomycin (15) and penicillin (10 U), but sensitive to carbenicillin (100), gentamicin (10), kanamycin (30), neomycin (30), nalidixic acid (30), novobiocin (5), polymyxin B (300) and tetracycline (30). The major cellular fatty acids $\left(>1 \%\right.$ of total fatty acids) are summed feature 3 (iso- $\mathrm{C}_{15: 0}$ $2-\mathrm{OH}$ and/or $\left.\mathrm{C}_{16: 1} \omega 7 c\right), \mathrm{C}_{16: 0}, \mathrm{C}_{18: 1} \omega 7 c, \mathrm{C}_{12: 0}$ and $\mathrm{C}_{10: 0}$ 3-OH. The major isoprenoid quinone is Q-9. The DNA G+C content of the type strain is $57.6 \mathrm{~mol} \%\left(T_{\mathrm{m}}\right)$.

The type strain, MS $-3^{\mathrm{T}}\left(=\right.$ KCTC $22612^{\mathrm{T}}=$ KACC $14032^{\mathrm{T}}$ $=\mathrm{JCM} 16046^{\mathrm{T}}=\mathrm{NBRL} 105641^{\mathrm{T}}$ ), was isolated from crude oil-contaminated seawater in the Taean area of Korea.

\section{Acknowledgements}

We cordially thank Professor Dr Lyudmila A. Romanenko (Pacific Institute of Bioorganic Chemistry, Far-Eastern Branch, Russian Academy of Sciences) for the gift of P. marincola KMM $3042^{\mathrm{T}}$ and Dr Ana E. Escalante (University of Minnesota) for the gift of $P$. cuatrocienegasensis LMG $24676^{\mathrm{T}}$. This research was supported by the Ministry of Environment of the Republic of Korea (grant no. 200805001-0033-0).

\section{References}

Anzai, Y., Kim, H., Park, J.-Y., Wakabayashi, H. \& Oyaizu, H. (2000). Phylogenetic affiliation of the pseudomonads based on 16S rRNA sequence. Int J Syst Evol Microbiol 50, 1563-1589.

Bernardet, J. F., Nakagawa, Y. \& Holmes, B. (2002). Proposed minimal standards for describing new taxa of the family Flavobacteriaceae and emended description of the family. Int J Syst Evol Microbiol 52, 1049-1070.

Bhattacharya, D., Sarma, P. M., Krishnan, S., Mishra, S. \& Lal, B. (2003). Evaluation of genetic diversity among Pseudomonas citronellolis strains isolated from oily sludge-contaminated sites. Appl Environ Microbiol 69, 1435-1441.

Bowman, J. P. (2000). Description of Cellulophaga algicola sp. nov., isolated from the surfaces of Antarctic algae, and reclassification of Cytophaga uliginosa (ZoBell and Upham 1944) Reichenbach 1989 as Cellulophaga uliginosa comb. nov. Int J Syst Evol Microbiol 50, 18611868.

Chun, J., Lee, J.-H., Jung, Y., Kim, M., Kim, S., Kim, B. K. \& Lim, Y. W. (2007). EzTaxon: a web-based tool for the identification of prokaryotes based on $16 \mathrm{~S}$ ribosomal RNA gene sequences. Int J Syst Evol Microbiol 57, 2259-2261.

Cole, J. R., Chai, B., Marsh, T. L., Farris, R. J., Wang, Q., Kulam, S. A., Chandra, S., McGarrell, D. M., Schmidt, T. M. \& other authors (2003). The Ribosomal Database Project (RDP-II): previewing a new autoaligner that allows regular updates and the new prokaryotic taxonomy. Nucleic Acids Res 31, 442-443.

Elkin, S. \& Geddes, D. (2003). Pseudomonal infection in cystic fibrosis: the battle continues. Expert Rev Anti Infect Ther 1, 609-618.

Felsenstein, J. (1985). Confidence limit on phylogenies: an approach using the bootstrap. Evolution 39, 783-791.

Gupta, S. K., Rekha Kumari, R., Om Prakash, O. \& Lal, R. (2008). Pseudomonas panipatensis sp. nov., isolated from an oil-contaminated site. Int J Syst Evol Microbiol 58, 1339-1345.

Hansen, G. H. \& Sørheim, R. (1991). Improved method for phenotypical characterization of marine bacteria. I Microbiol Methods 13, 231-241.

Johnsen, K., Andersen, S. \& Jacobsen, C. S. (1996). Phenotypic and genotypic characterization of phenanthrene-degrading fluorescent Pseudomonas biovars. Appl Environ Microbiol 62, 3818-3825.

Kahng, H.-Y., Nam, K., Kukor, J. J., Yoon, B.-J., Lee, D.-H., Oh, D.-C., Kam, S.-K. \& Oh, K.-H. (2002). PAH utilization by Pseudomonas rhodesiae KK1 isolated from a former manufactured-gas plant site. Appl Microbiol Biotechnol 60, 475-480.

Kimura, M. (1983). The Neutral Theory of Molecular Evolution. Cambridge: Cambridge University Press.

King, E. O., Ward, M. K. \& Rainey, D. E. (1954). Two simple media for the demonstration of pyocyanin and fluorescein. J Lab Clin Med 44, 301-307.

Kiyohara, H., Takizawa, N. \& Nagao, K. (1992). Natural distribution of bacteria metabolizing many kinds of polycyclic aromatic hydrocarbons. J Ferment Bioeng 74, 49-51. 
Komagata, K. \& Suzuki, K. (1987). Lipid and cell-wall analysis in bacterial systematics. Methods Microbiol 19, 161-207.

Kumar, S., Tamura, K. \& Nei, M. (2004). MEGA3: integrated software for molecular evolutionary genetics analysis and sequence alignment. Brief Bioinform 5, 150-163.

Lane, D. J. (1991). 16S/23S rRNA sequencing. In Nucleic Acid Techniques in Bacterial Systematics, pp. 115-175. Edited by E. Stackebrandt \& M. Goodfellow. New York: Wiley.

Levitski-Heikkila, T. V. \& Ullian, M. E. (2005). Peritonitis with multiple rare environmental bacteria in a patient receiving long-term peritoneal dialysis. Am J Kidney Dis 46, e119-e124.

López-Romalde, S., Magarinõs, B., Ravelo, C., Toranzo, A. E. \& Romalde, J. L. (2003). Existence of two O-serotypes in the fish pathogen Pseudomonas anguilliseptica. Vet Microbiol 94, 325-333.

Marmur, J. \& Doty, P. (1962). Determination of the base composition of deoxyribonucleic acid from its thermal denaturation temperature. J Mol Biol 5, 109-118.

Mikesell, M. D., Kukor, J. J. \& Olsen, R. H. (1993). Metabolic diversity of aromatic hydrocarbon-degrading bacteria from a petroleumcontaminated aquifer. Biodegradation 4, 249-259.

Mishra, S., Lal, B., Jyot, J., Rajan, S. \& Khanna, S. (1999). Field study: in situ bioremediation of oily sludge contaminated land using oilzapper. In Proceedings of Hazardous and Industrial Wastes Symposium, pp. 177-186. Edited by D. Bishop. Lancaster, PA: Technomic Publishing Co.

Mishra, S., Jyot, J., Kuhad, R. C. \& Lal, B. (2001). In situ bioremediation potential of an oily sludge-degrading bacterial consortium. Curr Microbiol 43, 328-335.

O’Mahony, M. M., Dobson, A. D., Barnes, J. D. \& Singleton, I. (2006). The use of ozone in the remediation of polycyclic aromatic hydrocarbon contaminated soil. Chemosphere 63, 307-314.

Onaca, C., Kieninger, M., Engesser, K.-H. \& Altenbuchner, J. (2007). Degradation of alkyl methyl ketones by Pseudomonas veronii MEK700. J Bacteriol 189, 3759-3767.

Oyaizu, H. \& Komagata, K. (1983). Grouping of Pseudomonas species on the basis of cellular fatty acid composition and the quinone system with special reference to the existence of 3-hydroxy fatty acids. J Gen Appl Microbiol 29, 17-40.
Palleroni, N. J. (1984). Genus I. Pseudomonas Migula 1984, $237^{\mathrm{AL}}$. In Bergey's Manual of Systematic Bacteriology, vol. 1, pp. 141-199. Edited by N. R. Krieg \& J. G. Holt. Baltimore: Williams \& Wilkins.

Palleroni, N. J. (1993). Pseudomonas classification. A new case history in the taxonomy of Gram-negative bacteria. Antonie van Leeuwenhoek 64, 231-251.

Prakash, O., Kumari, K. \& Lal, R. (2007). Pseudomonas delhiensis sp. nov., from a fly ash dumping site of a thermal power plant. Int J Syst Evol Microbiol 57, 527-531.

Saitou, N. \& Nei, M. (1987). The neighbor-joining method: a new method for reconstructing phylogenetic trees. Mol Biol Evol 4, 406425.

Sneath, P. H. A., Stevens, M. \& Sackin, M. J. (1981). Numerical taxonomy of Pseudomonas based on published records of substrate utilization. Antonie van Leeuwenhoek 47, 423-448.

Stolz, A., Busse, H.-J. \& Kämpfer, P. (2007). Pseudomonas knackmussii sp. nov. Int J Syst Evol Microbiol 57, 572-576.

Thompson, J. D., Higgins, D. G. \& Gibson, T. J. (1994). CLUSTAL W: improving the sensitivity of progressive multiple sequence alignment through sequence weighting, position-specific gap penalties and weight matrix choice. Nucleic Acids Res 22, 4673-4680.

Vancanneyt, M., Segers, P., Torck, U., Hoste, B., Bernardet, J.-F., Vandamme, P. \& Kersters, K. (1996). Reclassification of Flavobacterium odoraturn (Stutzer 1929) strains to a new genus, Myroides, as Myroides odoratus comb. nov. and Myroides odoratimimus sp. nov. Int J Syst Bacteriol 46, 926-932.

Wayne, L. G., Brenner, D. J., Colwell, R. R., Grimont, P. A. D., Kandler, O., Krichevsky, M. I., Moore, L. H., Moore, W. E. C., Murray, R. G. E. \& other authors (1987). International Committee on Systematic Bacteriology. Report of the ad hoc committee on reconciliation of approaches to bacterial systematics. Int J Syst Bacteriol 37, 463-464.

Weisburg, W. G., Barns, S. M., Pelletier, D. A. \& Lane, D. J. (1991). $16 \mathrm{~S}$ ribosomal DNA amplification for phylogenetic study. J Bacteriol 173, 697-703.

Whyte, L. G., Goalen, B., Hawari, J., Labbe, D., Greer, C. W. \& Nahir, M. (2001). Bioremediation treatability assessment of hydrocarbon-contaminated soils from Eureka, Nunavut. Cold Reg Sci Technol 32, 121-132. 